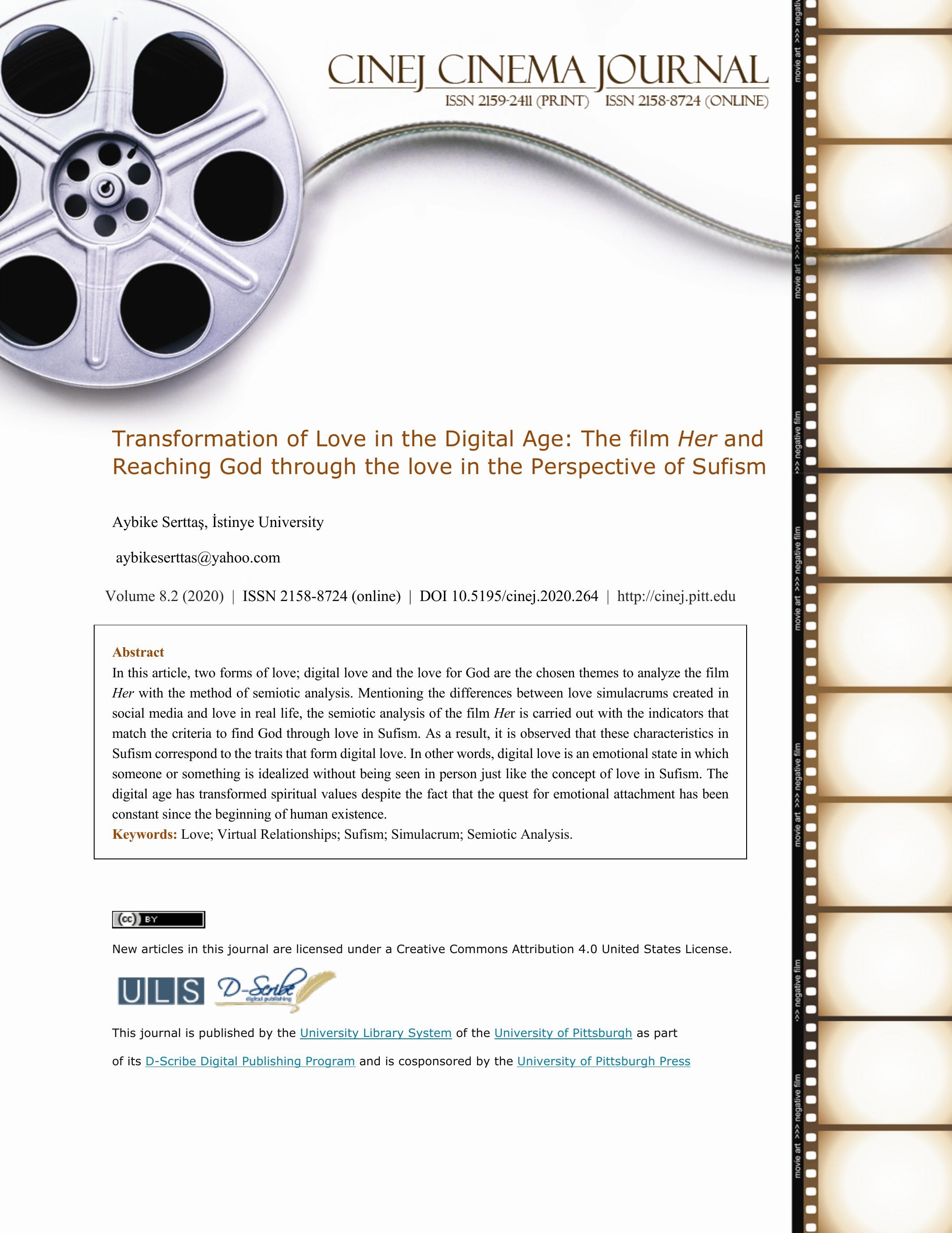




\section{Transformation of Love in the Digital Age': The film Her and Reaching God through the love in the Perspective of Sufism Aybike Serttaş}

\section{Introduction}

Can we say that the history of love is as old as the history of mankind? According to sources, it is possible to find traces of love even in the prehistoric period. Even though they are morphologically very different, the remnants of people living in this age are proof that love is a known feeling in that period. The reliefs, carvings and other details in the caves that survived 35 thousand years ago point to the existence of aesthetic concern and sensitivity, as well as the birth of love (Simonnet et al., 2014).

Her is a romantic - science fiction movie made in 2013. A newly separated, lonely and withdrawn character Theodore fails to go on a date with a young and beautiful woman. When he decides to use technology to cover the gap he has fallen into, Samantha enters the stage as a digital character. Samantha is an artificial intelligence application, an app that organizes Theodore's daily life, who turns out to be a virtual lover and falls in love with him. The desire of Theodore to share his feelings with this application and the possibility of reaching a true lover can be associated with the concept of love in Sufism - which is also called Islamic mysticism or tasawwuf. Islamic Sufism is based on the rule that there is no other genuine presence other than God. This is also known as the absolute beauty. This theory, which results from the search for the secret in creation, is to 
promote the existence of God which argues that there is only one entity, one real body, and it is

God. According to this, what we see around us is the various aspects of the existence of God. Sufist

love is for the infinite and the real lover, it is for God. The human body is composed of two main

parts called the body and the soul. The body is a mortal and temporal being, composed of four

elements which are earth, air, fire and water. The soul is immortal and carries all the qualities of

God. Therefore, man from God will return to God again.

Similarly, in Turkish Divan poetry, the characteristics of love are metamorphosis, abstraction and idealization. According to this, love is aestheticized and there is no possibility for sexual relationship. In these particular love states, the lovers mature as long as they cannot reach their lover. Idealization is created by putting physical distance between lovers. The inaccessibility of lover makes the loved one charming and emotions remain fresh. The lover doesn't want to reach the loved one since this way the spell will be broken. Beloved must remain unreachable (Gonel, 2010).

Before analyzing the image of love through the story of Theodore, it would be appropriate to examine how love, sufist concept of love and digital relationships are defined in the literature. These definitions will be supported by the simulation and simulacrum theory of Baudrillard. 


\section{The literature of love}

When the literature of love is examined, it is seen that the term is defined in quite different ways and subjected to many classifications. In one of the generally agreed definitions, love is depicted as strong, passionate love, extreme commitment felt for another person (Tufan and Yaluğ, 2010). Like rules and ceremonies about eating, love and sexuality lie in the depths of human nature.

Each culture necessarily includes them in their own system (Duby, 1992). For instance, according to Greek mythology, people used to be proud of being too strong and used to be four-legged hermaphrodite. This pride ended when the Gods divided the human into two parts. One person became a man with a female side and when he found the other half, he found love (Arda, 2015).

Human is a creature seeking close relationships. For an intimate relationship or love, there must always be another person (Atak and Taştan, 2012). Adolescents have other individuals in their social networks who are organized into a hierarchy according to their importance. A romantic partner is expected to become part of this hierarchy of figures (Furman and Wehner, 1994: 23). According to Atak and Taştan (2012), Freud defined love as the glorification of sexuality, Harlow as attachment behavior, Fromm as interest, responsibility, respect and understanding and Karnberg defines love as the abandonment of the self-borders in the existential dimension. 
In Sternberg's concept of triangular love, affection, passion and loyalty are the elements of love. The different combinations of these elements reveal eight types of love (Atak and Taştan, 2012). These are classified as liking, wildly love, empty love, romantic love, friendly love, silly love, perfect love and lack of love. Crazy love from these species (passion) is the obsession of the person whom the person dreamed of, rather than the person he really falls in love with. A true love experience can consist of a mixture of desire, longing, satisfaction and libido. Love and relationships are complex, neurobiological phenomena based on trust and belief, as well as the activation of the reward system in brain (Tufan and Yaluğ, 2010). According to Plato, in the first stage of love, one gets caught up in the beauty of an object. In the second stage he gains the ability to see this beauty in the universe, and in the final stage the person begins to remember the beautiful nature of the spiritual world which is truly platonic love (Arda, 2015).

According to Socrates love is the hunger of the human soul for the divine beauty. Love is not only to find the beauty, but also to create and to lead it. The mortal has the appetite to grow the seeds of eternity in the body (Aslanoğlu, 2000). There is a great similarity between the philosophy of Socrates and Sufism in which love holds an important role. We can surely say that the basis of Sufism is love.

According to Collins (2003) - whose definition is important to understand how digital love differs from face to face relationships - romantic relationships, like friendships are on-going 
voluntary interactions that are mutually acknowledged rather than being identified by only one member of a pair. Romantic relationships, however, also have a peculiar intensity and the intensity can be marked by expressions of affection —including physical ones and, perhaps, the expectation of sexual relations, eventually if not now.

\section{Digital Relationship}

In this century, in which a digital world and its conditions are rapidly penetrating our lives, our transformation cannot be explained only by the existence of technological capital. The changes that we can observe at every stage of our daily life are connected with technological capital and also the development of social capital. According to the statistics, while the world population increased by 1.6\% between 2014 and 2015, the number of internet users increased by $26 \%$ and the number of active social media users by $12 \%$ (Çetin, 2015). This increase came along with its transformation and this transformation has brought observable changes in the material and spiritual values. From food habits to holiday preferences, from our understanding of privacy to personal relations, many topics are included in the titles of this transformation. The concept of digital relationship, which is the subject of our study, is a product of the integration of the technological and social capital and it evokes the love for God in many ways. 
Until the advent of online dating sites in the 1990s and their recent and rapid proliferation on the Internet, the tasks associated with finding a romantic partner required that individuals meet face to face before they could get to know one another and determine their compatibility as a couple. Print media promotions and offline dating services existed for quite a while before the rise of online dating sites, however neither of these methods for meeting potential accomplices moved toward becoming standard about to the degree that web-based dating has today (Stephure et. al, 2009). Bryant and Sheldon (2017) mentioned that among the studies, the most commonly found motives for using an online dating site are seeking companionship, ease of communication, adventure, and looking for sexual partners. The writers suggest that the most influential reasons for using cyber dating are to develop relationships, to have fun and to hook up and their results indicate that more people have positive views of technology-based dating (2017).

Campbell and Murray (2015) defined technologies' creating additional spaces for individuals to pursue intimacy as a positive implication of technology and romantic relationships. Dating sites, social networking sites, and virtual worlds are attractive ways that individuals are now connecting with others when in search of new relationships, individuals with social anxiety report feeling safer to disclose personal information and to show their true self with other individuals when the interactions are mediated through a technology medium. 
The increase in digital relations is attributed to four main reasons (Brym and Lenton, 2001):

The increase in the number of single people compared to married people, career and time pressures, single people's spending more time on the Internet and decrease of romantic relationships in the workplace. The virtual sex, which occupy an important place in digital relations, have almost existed since the invention of the Internet. In an article published in 1993, S. Bright associates the emergence of virtual relationships with the spread of AIDS and other sexually transmitted diseases (Salter, 2011). Virtual sex has become an escape. Users prefer pop-up ads or virtual viruses to reallife users. These virtual worlds are a kind of sanctuary where the real body is safe and protected, only the mind and the heart are revealed, and romance is produced. Online interaction is never physical. Virtual visuals are sent, but it is not possible to fully trust. Although the webcam offers some possibilities, the spaces are filled with the power of mind. The virtual space creates its own truth: Body language, eye gaze, not pure truth. In spite of this, since the Internet has become a living space, there has been love in virtual worlds (Salter, 2011).

Caughlin and Sharabi (2013) mentioned that individuals in close relationships can integrate and segment different communication modes that are used in romantic relationships including private and public Internet, Internet and video chat, text and instant messaging, and telephone calls. Using sounds, gestures, photos and videos enables Internet users to produce their own online 
physical reality (Sayar and Senkal, 2014). Orosz at al. (2015), mention about the development of new rituals of online relationships which could be assumed as pledge of allegiance. For instance, they conclude that disclosing relationship status is a modern, online tie-sign which can be interpreted as an expression of commitment with a digital wedding ring. The real intimacy of online relations - not only friendships, but more specific - is also in danger, as real proximity is related to trust, and virtual personalities are able to shape their physical characteristics, characters, interests, ages, professions, and even sexes according to their personal fantasies. According to Donn and Sherman (2002), this has become part of the folklore of the Internet. Some of the risks are similar to those in meeting people through personal ads, but computer mediated communication $(\mathrm{CMC})$ makes extended dissembling all the more possible. This act of taking advantage of the anonymity afforded by CMC in order to purposefully deceive others through false images or identity is attributed to disinhibition.

Kellerman (2014), who compares the needs of the real world and the virtual world through Maslow's hierarchy of needs, stated that the virtual space is a very important place to reach when it comes to the higher levels of human needs and feeling of love and belonging. In the case of the elimination of human needs, competition between the real and virtual spaces appears in different ways. Internet-based social relations can be established to compete with relationships in real physical space (Kellerman, 2014). Just as the user can fill in the gaps with imagination, it seems 
possible to rebuild the person's physical and intellectual identity in online communication channels. With the opportunities of the Web, a user can redesign himself as he wants and can be the one, he desires to be in the real world by escaping his real body (Almjeld, 2014). From this point on communication technology is blamed for inventing a dreamland, encouraging people to quickly and openly express romantic feelings and sexual attraction instead of sticking to a matterof-fact information exchange (Döring, 2002).

Wysocki and Childers (2011) describe this 'creative' aspect of online relations as follows: Meeting in virtual space allows the participants the ability to create detailed images of the absent and invisible body, freed from their burdensome material selves they become fluid entities, overcoming those societal stigmas inscribed on the body-race, gender, age, size, beauty. Their research suggests the possibility that as technology changes, the way that people find each other and the way they attract a potential partner also changes. Sullivan and Ronis (2013) also refer to the changing flirting concept. Sending nude or seminude photographs or sexting are increasingly used as modern forms of flirting. Adolescents also report the use of chat rooms or online dating services to connect with others. Research examining the shifts in adolescents' online and offline interactions has had trouble keeping up with the dramatic changes in technology use among youth and the impact that technology use has on their intimate relationships. Hamilton (2016) emphasizes 
how the Internet has fundamentally changed the fabric of the dating environment either. According to the writer, the online dating environment changes the way in which we present ourselves and perceive others. Hyperpersonal communication may lead daters to create an idealized version of their communication partner in their mind, and differences between that ideal and reality may become greater the longer they communicate online without meeting.

Wright (2017) has documented the considerable changes which have precipitated a movement away from the anonymity of the 1990s Internet toward an increasing interweaving of online and offline life. As a result, offline connections exert a profound influence on emerging adults' online identity expressions. To cope with the challenge of managing developing identities in the face of persistent digital footprints, emerging adults often respond by carefully packaging, editing, and curating their online identity portrayals.

Hobbs et al. (2017) suggest that users of dating apps view them as welcome intermediaries in the search for companionship, love, sex and intimacy, and a majority of individuals continue to value and seek these social phenomena, and a merely using the technology as tools to pursue partnerships. They feel they have more romantic and relationship possibilities than previous generations, and they feel these technologies give them great agency in regard to pursuing and meeting potential lovers and potential companions. 


\section{Love as the highest level of Sufism}

The issue of love, which has a great influence on the formation of Islamic Persian and Turkish literature, has always been a concept that could be applied to terms such as beauty, unity, metaphor and truth, and to assess the existence and creation (Baltac1, 2014). One of the issues that influenced the writing of love in Islamic philosophy is that Plato's Phaedrus dialogue which defined love as a transcendental type of mental illness and this situation has two divine and physical characteristics (Pattabanoğlu, 2016). According to Plotinus, love which is one of the ways that will lead to God, causes the lover to turn to beauty first and then to see this beauty in arts, sciences and virtues. Fârâbî contributed to the philosophy of love with his ideas about love, especially for Ibn Sina and later thinkers. He was heavily influenced by Neo-Platonism according to which Plotinus acknowledges that good can be known through enlightenment after long years of dealing with a kind of intuition and dialectic, because it is the cause of existence and it is above the world of ideals. Because love is the knowledge that provides good and love for Plotinus is a purification, an enlightenment.

In Her, the main character, Theodore, embodied his need for love with an application. For Theodore this application's virtual presence is not crucial. Theodore does not limit his love with a virtual being, he is satisfied with the changing perspective of his life through this unique 
experience. Most of the Divan poets considered material love as a way of reaching to spiritual love. In true love, the lover is God, in metaphorical love it is a human (Kazan, 2010). The first stage of love in Sufism is to see the reflection of the beauty of the face. This beauty of God can appear in a person or in nature. Realizing the beauty of lover is the first step towards love, and it is a mirror, than becoming aware that God is the true being of absolute beauty is part of the path of love (Turkdogan, 2008). At the same time, the lovers who pass these insight tests, do these exams in four stages: Separation and longing, the examinations presented to the lover, the abolition of duality, and finally the realization of reunion and divine love.

Love is the highest level in Sufism, which is the closest level to observe human mystery, and God in the form of a beautiful face. The ultimate goal of humanity is the range of love (Turkdogan, 2008). In Shaykh Galip's concept of the love for God, the doctrine of love envisions dissolving and kneading man in trouble and suffering, until he exposes the pure matter in the essence of his material existence. Many studies related to Leyla and Mecnun focus on the idea of metaphorical love and metaphor. Beauty of Love likewise emphasizes perseverance in true love. In two stories, lovers break up and reunite at the end of the story (Kacar and Kosik, 2014). Metaphorical love is embodied in many lines of Mevlana (Rumi). The question of why there is pain in love is answered as follows: The true lover does not run away so the hardness is for finding 
the person who does not give up loving easily. In this answer, a test method that tries people who are metaphorically in love is hidden (Kaval, 2011).

The theme of sufist love is also included in the fairy tales around the world. In the Grimm tale Loyal Servant, a single room in the palace is prohibited to enter (Aykanat, 2013). This room has a dangerous portrait which is reflecting a very beautiful woman. One day the Young King persistently wants to look at it, and the servant cannot resist his king, so he opens the door of the room. The Young King facing the painting cannot withstand the greatness of the image of the woman and falls unconscious. The love of the young king to the unattainable one begins at that moment.

If we continue to follow the traces of sufist love in Mevlana's Mesnevi we find the idea that the person who is right in his love is not connected to a living creature. The food of the lover is to fall in love with bread without bread because the lover has no business with other beings (Kaval, 2011). In the essence of Mesnevi, it is noteworthy that the important thing is the meaning of love, not the form of the creature. Mecnun in 572. couplet says that "You are a sign from beginning to this time come and look me with my eye." In fact in accordance with the principle Vahdet-i Vücud which means unity of the body as a reference to God Mecnun loves the creation because of the creator (Derdiyok, 1998). The Sufi metaphysics is mainly developed 
around the idea of unity. Thus the being consists of an "absolute being", and images of its reflections in the mirror. Mevlana's lover does not need anything nice. All the good things and beauties that are necessary to reach God are already given to humankind in the best way and they are equipped with this system and capacity. Evil is neither at the core of any being. He argues that everything is love in a sense in the other words there is love in everything (Kıliç and Arslan, 2007). How close are the views of Mevlana to the simulacrum? According to Mevlana what is called existence does not exist in real sense. They are seen as a metaphor because of being relevance to the true being (Tuncbilek, 2007).

\section{Simulacrum and the imitation of truth}

In an age when everything that is physical or even notional are copied and the copy sometimes becomes more marketable the term hyperreality refers to the current condition of contemporary society where images, signs, models, simulations, and simulacra are no longer associated with any real referents. Rather they circulate detached from material objects and ideals such as the true income of an enterprise or the intrinsic value of financial instruments (Macintosh, 2003).

J. Baudrillard defines simulacrum as the view to be perceived as a reality simulation is no longer that of a territory, a referential being, or a substance (1994). In the first chapter of his work, he writes the quote from Ecclesiastes suggesting the reader that simulacrum is the reality with the 
words "The simulacrum is never that which conceals the truth--it is the truth which conceals that there is none." (1994). Baudrillard's definition for simulation which is also the subject of many movies and works of art is to pretend to have something actually we don't have (1994).

Ulus Baker, states that we are under image bombardment (http://www.korotonomedya.net/kor/index.php?id=21,185,0,0,1,0). According to Baker, images are not representations of reality, they leave different effects on consciousness as long as they are decoded as a kind of simulation. There is universal and natural consensus that even the most realistic picture is "a representation of reality". However, the technical image is not, for example, a photograph, a reality itself, or a representation. It is nothing more than a trace of reality left on a photographic plate. Similarly Baudrillard says that we live in a universe that resembles the original in a way that can be said everywhere (1994). According to this, things produce their own twin. Everything related to life - for example lost abilities, lost bodies, lost sociality or old-tasted food, in short, everything - is tried to be restored to the old function.

Umberto Eco (1983) exemplifies the production of twins by American society. According to Eco, what is completely defined as true is completely fake. The absolute is presented as an unreal, true being. The indicator is intended to be what makes the distinction of the reference mechanism of the original reference absolute. This is not the image of the thing, it is a kind of packaging, in 
other words its pair. The American imagination wants the real thing, and in order to reach it, it must produce absolute falsity; that is, the boundaries between reality and illusion are blurred (Eco, 1983). In summary, the simulation space is a space in which the real and the model intermingle and simulating is not pretending. Finally, and with the most cited statements of Baudrillard (1994) which of those have been a trigger to connect digital relationships, reality and simulation in this research, the successive phases of the image starts with the reflection of a basic reality. In the second phase it masks and perverts a basic reality. In the third one, it masks the absence of basic reality and in the last phase it bears no relation to any reality or whatsoever: it is its own pure simulacrum. In other words, in the first case, the image is a good appearance: the representation is in the order of sacrament but in the fourth, it is no longer in the order of appearance at all, but of simulation.

\section{Method and analysis of Sufist love indicators in $\mathrm{Her}$}

Umberto Eco (1976) has suggested that a sign can be taken as substituting for something else which does not have to exist or be somewhere at the moment in which a sign stands for it (1976) which made us think that signs can be used to represent the reality or simulacrum. Eco (1976) indicated that semiotics is concerned with everything that can be taken as a sign and a sign is everything which can be taken as significantly substituting for something else. Peirce (1991) on the other hand, describes a sign as an object which stands for another to some mind. According 
to him a sign like any other thing must have qualities which belong to it whether it be regarded as

a sign or not. As the indicator does not replace an object in all respects, but rather a kind of idea

(Rifat, 2000), in semiotics, indicator, interpret and object are Ch. S. Peirce's most important triad

of classification used in text analysis and these tripartite terms are used in the analysis of the movie.

A. A. Berger (2005) has been concerned with the ways semiotic analysis can be used to explicate the television narrative, films, comics, architecture etc. in which communication is important. His checklist for communication products has been created for the analysis of the sufist love indicators that have become simulacrum in Her.

Based on the theoretical part of the study, the love for God can be measured or identified with seven action paradigms. These themes are:

1. The presence of physical distance

2. Inaccessibility, inability to reach

3. Recognizing the beauty of lover

4. Separation and sadness

5. Examinations

6. The disappearance of duality, to be sole

7. Suffering 
Examining Her through the concept of love for God themes, it was detected that the story of the movie included the traits of the love for God and this observation was turned into a threecolumned table. The column showing the indicator describes what is represented in the film, the second column shows the time in which the act takes place, and the third column shows which one of these themes corresponds to the traits of the love for God. The action in the third column is indicated by action paradigms numbered from 1 to 7 above.

Table 1. The indicators bearing resemblance to the concept of the love for God in Her's narrative

\begin{tabular}{|c|c|c|}
\hline Indicator & $\begin{array}{l}\text { Time } \\
\text { Code }\end{array}$ & Theme Number \\
\hline $\begin{array}{l}\text { Theodore, who installed the operating system and met Samantha, is happy doing his daily } \\
\text { activities at work with her }\end{array}$ & $16: 00$ & 3 \\
\hline Theodore dates with a real woman & $35: 15$ & 5 \\
\hline Samantha wants to touch Theodore and be there with him & $41: 00$ & 2 \\
\hline Theodore and Samantha make love & 43:00 & 6 \\
\hline They spend a day together & 48:00 & 3 \\
\hline $\begin{array}{l}\text { Theodore tells Samantha about his past, his secrets and feelings which he has never told } \\
\text { anyone before }\end{array}$ & $50: 00$ & 6 \\
\hline Theodore sees his ex-wife and feels confused & $68: 00$ & 4 \\
\hline A colleague invites Theodore and Samantha to dinner & $71: 00$ & 1 \\
\hline $\begin{array}{l}\text { Theodore's confusion continues and he does not communicate with Samantha in the following } \\
\text { days }\end{array}$ & $73: 00$ & $4-7$ \\
\hline Samantha wonders what it feels like to be human & $76: 00$ & 7 \\
\hline With the help of a stranger, Samantha tries to make love with Theodore & $80: 00$ & $7-1$ \\
\hline Theodore questions the reality of Samantha's feelings & $82: 00$ & 7 \\
\hline Theodore wants to end their relationship as a result of this inquiry & $83: 00$ & 5 \\
\hline They separate & $84: 00$ & 4 \\
\hline The separation is temporary and Samantha composes a music that depicts their unity & $90: 00$ & 6 \\
\hline Theodore tells his close friend about Samantha & 93:00 & 3 \\
\hline Theodore suffers from what Samantha says & 100 & 7 \\
\hline Theodore can't reach Samantha & 103 & 7 \\
\hline Samantha makes an explanation about Theodore's not being able to find her & 107 & 2 \\
\hline
\end{tabular}




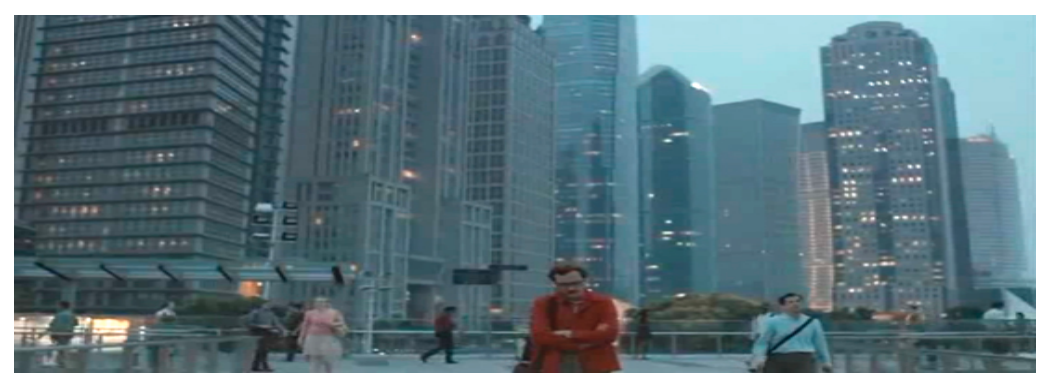

Figure 1. Film Stills from Her (2013)

Realizing the beauty of lover (at $16^{\text {th }}$ minute): Theodore begins to understand that the operating system he installs is not a simple program. Accompanying him in different moments of his daily life, this artificial intelligence makes him laugh, provides a pleasant time in the workplace and makes life easier. Theodore realizes that this practice makes him feel better more than he expected.

Examinations (at $35^{\text {th }}$ minute): Although Theodore is pleased with the time he spent with Samantha, he feels an internal pressure to do normal activities that society expects him to do. For this reason, Samantha sets Theodore a date with a real woman even though he doesn't want to. This is the first test that will lead him to understand who is in his mind for Theodore, and a process that allows her to discover the sense of jealousy for Samantha.

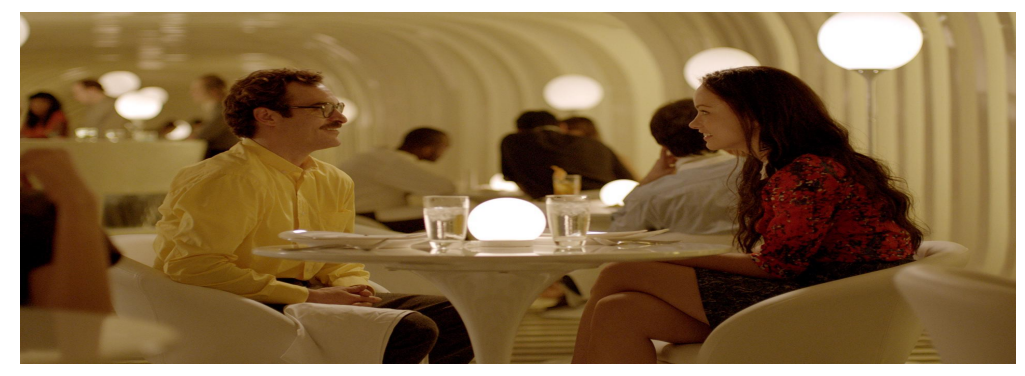

Figure 2. Film Stills from Her (2013) 
Inaccessibility (at $41^{\text {st }}$ minute): Samantha questions the relationship between them in every way and says "If only you were with me right now, I could touch you." In many scenes of the two lovers, they feel that they cannot reach each other for both internal and external reasons.

Disappearance of duality, (at $43^{\text {rd }}$ minute): Despite all the obstacles and impossibilities, Theodore and Samantha make love. After this stage, they feel that they are one and that there is no obstacle for them to overcome.

Realizing the beauty of lover, (at $48^{\text {th }}$ minute): Theodore and Samantha spend a beautiful day together. They walk around in the open air, and chat. This positive environment is supported by yellow tones. Theodore is very happy.

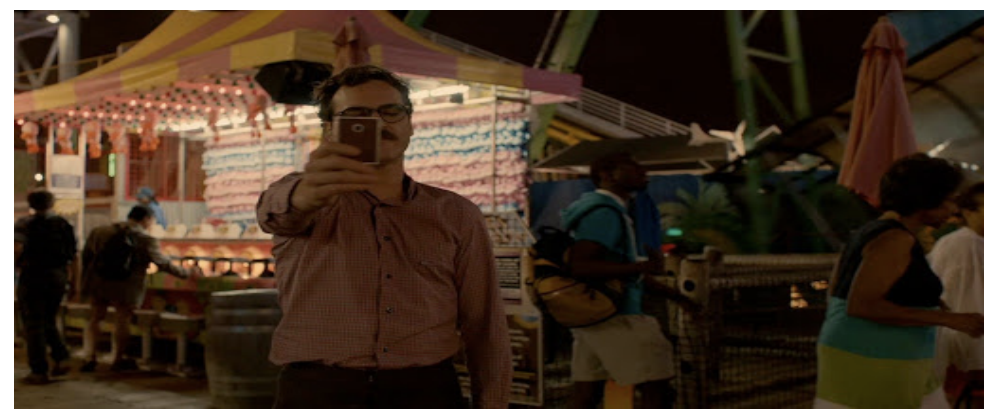

Figure 3. Film Stills from Her (2013)

Disappearance of duality, (at $50^{\text {th }}$ minute): Theodore continues to satisfy his need for spiritual integration through the operating system. He tells about his past, his feelings, disappointments, and his former love. Samantha becomes his real emotional partner. 
Separation and sadness, (at $68^{\text {th }}$ minute): Theodore meets his ex-wife. He is confused even though the purpose of the meeting is to settle their divorce. While his wife wanders in his mind, all his beautiful memories emerge, and his connection with the operating system weakens. Theodore stays away from the operating system for a while.

The presence of physical distance (at $71^{\text {st }}$ minute): One of Theodore's colleagues invite the couple to dinner. Samantha participates in the invitation, but of course only with the tiny device she has uploaded and the sound transmitted from her. Samantha will never physically exist in his house, or social life.

Suffering, (at $76^{\text {th }}$ minute): Theodore's confusion continues. He won't communicate with Samantha for a while. During this period, he does not laugh like before, he lives in a state of contemplation. Theodore is not happy.

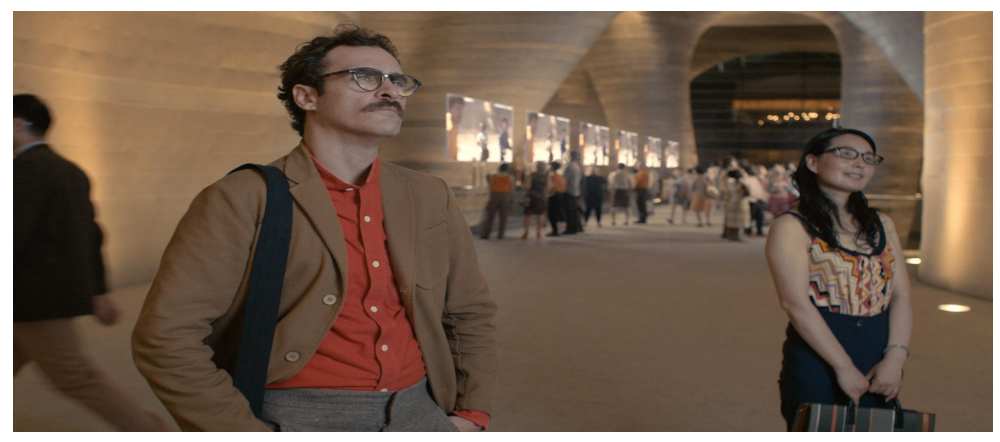

Figure 4. Film Stills from Her (2013)

Suffering, (at $84^{\text {th }}$ minute): At this moment of the movie and in many scenes, a similar suffering theme is covered. Samantha seeks answers to many questions about her existence. The 
main question is what a feeling is. Samantha wants to experience all emotions regarding humanity.

She is worried because of the fact that this is possible only to some extent.

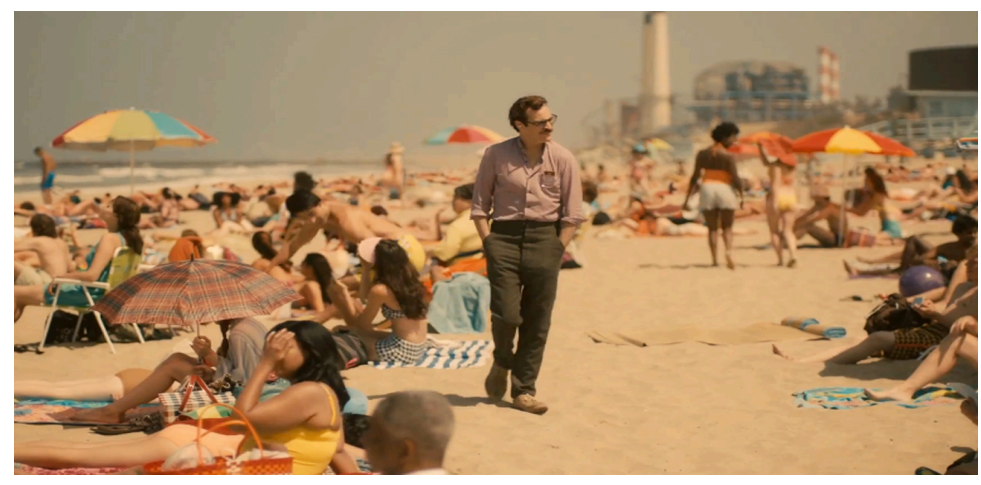

Figure 5. Film Stills from Her (2013)

Samantha's attempt to be with Theodore by means of a person at $80^{\text {th }}$ minute and her discussion with Theodore at 82 nd minute are the reflections of this agony. In this discussion, Theodore asks Samantha why she breathes heavily although she doesn't need oxygen. This reveals the problem of a new test. At 83rd minute they question the relationship between them and they break up.

At 90th minute of the film, Samantha composes a music track. Samantha describes this work as a photo of what they mean together. Theodore says he can see Samantha in it. After this moment, we can assume that they accepted each other as they are. 


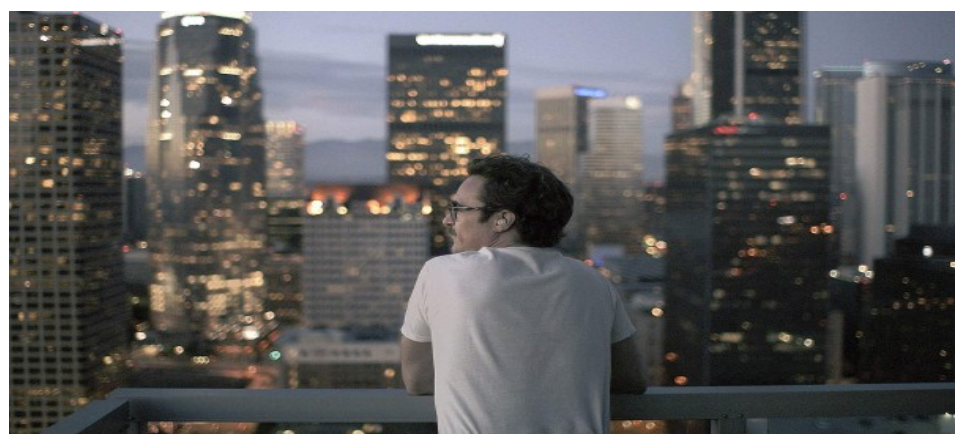

Figure 6. Film Stills from Her (2013)

Theodore describes the beauty of his lover to a friend at 93rd minute. At 100th minute there is still suffering. Samantha questions the existence of herself with this sentence "None of us are a person we were a minute before and it was painful." Between 105th and 106th minutes, when Theodore learned that she was in love with others, the suffering he had was not different from that of any deceived lover. In this case, Samantha emphasizes the inaccessibility by saying "I am both yours and not yours."

The dialogue at 117 th minute of the movie is important as it is more than just reaching a person. Theodore understands everything and asks Samantha to leave him. Her answer is: "Think like I'm reading a book. I can still feel you, but I can't do it here anymore. In a place similar to the material world. You have to let me go." Theodore is only a tool in Samantha's story, a sensation of a search, a quest, but it is not all. Samantha understood that she didn't need to be content with a part of the whole to reach the full spectrum of emotions she sought. 


\section{Conclusion}

Love, which is as old as human history, has been subject to different narratives, in verbal, written or other forms many times. However, both in personal statements and in academic literature, we can assume that there is no agreed definition of love. There are different approaches to love in various cultures and these approaches are reflected in many moments of life, from marriage ceremonies to social rules. Love also carries a cultural depth. In the digital age, the effects of technological developments on social life are discussed in all aspects. Digitalization has brought the transformation of material and spiritual values, which should be examined (and studied) in terms of its impacts on new media producers, users and also on traditional media consumers and professionals.

In this transformation environment, the definition of communication has expanded. Human relations began to be defined with new terms such as digital love, virtual flirting, virtual sex, digital actors and with new codes. In a sense, with the mean world syndrome conceptualized by G. Gerbner (1998), people who are distant to the outside world have become preferable to the satisfaction of their romance needs in a safe and virtual manner in the safe environment of their home. In a world where everything has become a marketable commodity, the main character of the analyzed film has sought to fill his emotional void with the product he bought. In fact, this scenario does not address to a different view from what today's advertisements promises. In 
capitalist economies, advertisements sell more psychological benefits to the consumer than the tangible benefits of products which refer to love, peace, joy, happy family, popularity, sex and so on, and consumers are immensely affected by these references. In the film, the main character thought that he could establish an emotional bond with the product he purchased and did not hesitate to be involved in an evolved digital relationship model and this digital love of the main character is strikingly similar to the concept for the love for God in Islamic mysticism. Love for valentine is a step to reach true love. There is no attempt to reach God in Her, but the digital love in the film includes the use of the imagination as a tool for the realization of the desired emotions.

The reality of God and technology is an endless controversy. In both cases - the love for God through its creations and manifestations or in digital love - things that are not concrete can be sought. The effects of these questionable emotions on human beings were observed and conceptualized in this study. While the love for God is the effort to reach God through the perceptible parts of the creator on earth, digital love is to make an effort to reach man due to technology - which is in other words the God of the modern world.

In this context, the two concepts -the love for God and digital love- have the same processes, an infinite loop of induction and deduction. In digital love, Samantha is the manifestation of man, while the manifestations of God in the concept of love for God are every 
beautiful thing that man can perceive spiritually and physically. Samantha is a product of technology, and this artificial intelligence is trying to reach man as its God. In a sense, man's daily life is similar to the concept of the love for God for artificial intelligence. Samantha's enthusiasm for everyday matters and every little thing she encounters are the signs of this concept of the love for God. Man is the created one while he is searching for God, yet he is the creator when it comes to digital love.

Baudrillard (1994) states that things produce their own twins, and they break away from the essence of reality, but a system of reality is formed that resembles the original. In addition to the many values and habits transformed, the digital age produced a twin of Sufism that has a different character. Emotions, values, communication processes, lifestyles, social structures, materials as well as the spiritual elements of culture have been redefined, and love has a new definition, too. The new age is producing new twins with great speed, as there are some things that have been going on in the same way since the beginning of humanity (see Maslow's hierarchy). As these twins multiply, alienation and commodification do not fall from the top of the list of modern human problems.

Man has changed and is changing. Evaluations on love are essentially a fixing point that can be used to observe thousands of years of human transformation. Sufism, Divan literature, mythology, love in fairy tales, love in cinema or digital love, all contain clues about the search of 
man on earth and the nature of this quest. In order to carry out an even broader evaluation of the

results of the study and to develop new perspectives, conduction of in-depth interviews with new

media users who state that they are experiencing digital relationships may be suggested.

\section{BIBLIOGRAPHY}

Akser, M. (2015). Old and new methods for online research: The case of online dating. In Degim, A., Johnson, J., Fu, T. (Eds.) Online Courtship: Interpersonal Interactions Across Borders, (pp. 29-35). Amsterdam: Institute of Network Cultures.

Almjeld, J. (2014). A Rhetorician's Guide to Love: Online Dating Profiles as Remediated Commonplace Books. Computers and Composition. 32, 71-83.

Arda, Z. (2015). Love aesthetics and painting, Idill, 4(16), 81-106.

Aslanoğlu, İ. (2000). Love and human philosophy in Mevlana. Hacı Bektaş Veli Research Journal, 16, 175-197.

Atak, H., Taştan, N. (2012). Romantic relationships and love. Current Approaches in Psychiatry, $4(4), 520-546$.

Aykanat, T. (2013). An interspecies comparison on Grimm tales and classic love mesnevi. The Journal of Academic Social Sciences, 6-5, 165-198.

Baker, U. Why Godard? (nd) Avaliable at:

http://www.korotonomedya.net/kor/index.php?id=21,185,0,0,1,0 Accessed on [12.15.2018].

Baltacı, H. (2014). The Sufi Content of Love: Ahmed al-Ghazali, Baklî and Irâkî Line. Journal of Sufism, 34(2), 23-44. 
Baudrillard, J. (1994). Simulacra and simulation. (Tr. by Sheila Faria Glaser). USA: Michigan University Press.

Baudrillard J. (2001). Simulacra and simulation. In: Baudrillard J (ed.) Selected Writings. Palo Alto, CA: Stanford University Press, pp. 166-184.

Baym, N. K. (2015). Personal connections in the digital age. Malden, MA: Polity Press.

Berger, A.A. (2005). Media analysis techniques. USA: SAGE publications.

Bryant, K., \& Sheldon, P. (2017). Cyber dating in the age of mobile apps: understanding motives, attitudes, and characteristics of users. American Communication Journal, 19(2), 115.

Brym, Robert J., Lenton, Rhonda L. (2001) Love online: a report on digital dating in Canada. Toronto: MSN:CA.

Caughlin, J. P., \& Sharabi, L. L. (2013). A communicative interdependence perspective of close relationships: The connections between mediated and unmediated interactions matter. Journal of Communication, 63(5), 873-893.

Campbell, E. C., \& Murray, C. E. (2015). Measuring the impact of technology on couple relationships: The development of the technology and intimate relationship assessment. Journal of Couple \& Relationship Therapy, 14(3), 254-276.

Collins, W. Andrew. (2003). More than myth: the developmental significance of romantic relationships during adolescence. Journal of Research on Adolescence, 13(1), 1-24.

Çetin, E. (2015). Photos, location / location notification sharing and privacy in social networking: case of Facebook. International Journal of Social Research, 8(41), 779-788.

Derdiyok, Çetin. (1998). Leylâ and Mecnûn in Mesnevi Manevi ", IXth National Mevlânâ Congress Booklet, Selçuk University, pp. 75-84.

Donn, J. E., \& Sherman, R. C. (2002) Attitudes and practices regarding the formation of romantic relationships on the Internet. CyberPsychology \& Behavior, 5(2), 107-123. 
Döring, N. (2002). Studying Online-Love and Cyber-Romance. In B. Batinic, U.-D. Reips \& M. Bosnjak (Eds.), Online Social Sciences (pp. 333-356). Seattle, Toronto, Switzerland, Germany: Hogrefe \& Huber Publishers.

Duby, G (Ed). (1992). Love and sexuality in the West. İstanbul: İletişim.

Eco, U. (1983). Travels in hyperreality essays, USA: A Helen and Kurt Wolff Book.

Eco, U. (1976). A theory of semiotics. Bloomington: Indiana University Press.

Furman, W., \& Wehner, E. A. (1994). Romantic views: toward a theory of adolescent romantic relationships. In R. Montemayor, G. R. Adams, \& T. P. Gullotta (Eds.), Advances in adolescent development: An annual book series, Vol. 6. Personal relationships during adolescence (pp. 168-195). Thousand Oaks, CA, US: Sage Publications, Inc.

Gerbner, G. (1998). Cultivation analysis: An overview. Mass communication and society, 1(3-4), 175-194.

Gönel, H. (2010). About the Valentine in Divan poetry. Turkish Studies, 5(3), 208-222.

Hamilton N.F. (2016) Romantic Relationships and Online Dating. In: Attrill A., Fullwood C. (eds) Applied Cyberpsychology. London: Palgrave Macmillan.

Hobbs, M., Owen, S., \& Gerber, L. (2017). Liquid love? Dating apps, sex, relationships and the digital transformation of intimacy. Journal of Sociology, 53(2), 271-284.

Kaçar, M., Koşik, S.H. (2014). Fuzuli'nin Leylâ Vü Mecnûn Mesnevisinin Dibacesi Hakkinda Bazi Mülahazalar (Some provisions about the foreword of Mathnawi of Leyla and Majnun by Fuzuli). Uluslararası Türkçe Edebiyat Kültür Eğitim (TEKE) Dergisi, 3(2), 154-166.

Kaval, M. (2011). Love and lover in Mesnevi. EKEV Akademi Dergisi, 15(49), 117-128. 
Kazan, Ş. (2010). Şeyhülislam Yahya Divanında „Aşke in Anlam Çerçevesi

Meaning framework of love Şeyhülislam Yahya's divan. Turkish Studies, 5(3), 336-367.

Kellerman, A. (2014). The satisfaction of human needs in physical and virtual spaces. The Professional Geographer, 66(4), 538-546.

Kılıç, C, Arslan, H. (2007) İslam Düşüncesinde Aşk Metafiziği (Metaphysics of love in Islamic thought). New World Sciences Academy, 2(4), 321-351.

Macintosh, N. B. (2003). From rationality to hyperreality: paradigm poker. International Review of Financial Analysis, 12(4), 453-465.

Orosz, G., Szekeres, Á., Kiss, Z. G., Farkas, P., \& Roland-Lévy, C. (2015). Elevated romantic love and jealousy if relationship status is declared on Facebook. Frontiers in psychology, 6(214), 1-6.

O'Sullivan, L. F., \& Ronis, S. T. (2013). Virtual cheating hearts: Extradyadic and poaching interactions among adolescents with links to online sexual activities. Canadian Journal of Behavioural Science / Revue canadienne des sciences du comportement, 45(3), 175-184.

Pattabanoğlu, F. Z. (2016) Yeni Platonculuğun Fârâbî'nin Aşk Anlayişina Etkileri (The effects of new Platonism on Fârâbî's understanding of love). Ekev Akademi Dergisi, 20(65), 211 238.

Peirce, C. (1991). On the Nature of Signs. In Hoopes J. (Ed.), Peirce on Signs: Writings on Semiotic by Charles Sanders Peirce (pp. 141-143). University of North Carolina Press.

Propp, V. (2010). Morphology of the folktale. Austin: University of Texas Press.

Rifat, M. (2000). The theories of linguistics and semiotics in the 20th century. Istanbul: YKY.

Salter, A. (2011). Virtually yours: Desire and fulfilment in virtual worlds. The Journal of Popular Culture, 44(5), 1120-1137.

Sayar, K., \& Senkal, Z. (2014). Facebook Loves: Depression, Psychosis and Online Romance, Report of Three Cases. Journal of Mood Disorders, 4(1), 26-33. 
Simonnet, D. et al. (2014) The most beautiful history of love. Istanbul: Turkey İş Bankası.

Stephure, RJ, Boon, SD, MacKinnon, SL, Deveau, VL. (2009). Internet initiated relationships: Associations between age and involvement in online dating. Journal of Computer-Mediated Communication, 14(3), 658-681.

Tufan, Ali E., Yaluğ, İ. (2010) “Aşk” Fenomeni ve Sevgi İlişkilerinin Nörobiyolojisi (The phenomenon of love and the neurobiology of love relationships). Psikiyatride Güncel Yaklaşımlar, 2(4), 443-456.

Tunçbilek, H. H. (2007). Mevlânâ'da Vahdet-İ Vücûd Telâkkisi (Worship of body in Mevlana). Harran Üniversitesi İlahiyat Fakültesi Dergisi, 18(18), 55-60.

Türkdoğan, M.G. (2008) Bir Bildungsroman Olarak Aşk Mesnevileri (The love mesnevis as bildungroman). EKEV Akademi Dergisi, 37(12), 227-238.

Wright, M. (2017). Identity, Sexuality, and Relationships among Emerging Adults in the Digital Age. In: Umemura, T. (ed.) Advances in Human and Social Aspects of Technology (AHSAT). USA: IGI Global.

Wysocki, D. K., \& Childers, C. D. (2011). "Let my fingers do the talking”: Sexting and infidelity in cyberspace. Sexuality \& Culture, 15(3), 217-239.

\section{ENDNOTES}

${ }^{1}$ A general literature review on the subject of love in digital media can be found in Akser (2015) and Baym (2015). 